\title{
The Effect of Blended Learning in Enhancing Female Students' Satisfaction in the Saudi Context
}

\author{
Sarah Al-Hassan ${ }^{1} \&$ Nadia Shukri ${ }^{2}$ \\ ${ }^{1}$ The English Language Institute, King Abdulaziz University, Jeddah, Saudi Arabia \\ ${ }^{2}$ The English Language Institute, King Abdulaziz University, Jeddah, Saudi Arabia \\ Correspondence: Nadia Shukri, English Language Institute, King Abdulaziz University, Jeddah, Saudi Arabia. \\ Tel: 966-056-688-0607. E-mail: ndshukri@gmail.com
}

Received: March 1, 2017 Accepted: May 26, 2017 Online Published: May 30, 2017

doi: 10.5539/elt.v10n6p190 URL: http://doi.org/10.5539/elt.v10n6p190

\begin{abstract}
The present study intended to investigate the effect of utilizing Learning Management System (LMS), Blackboard ${ }^{\circledR}$ on enhancing English as a Foreign Language (EFL) female students' satisfaction in the Saudi

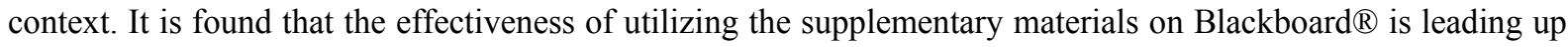
to EFL students' satisfaction. Since, Blended Learning (BL) model could stimulate a classroom setting with activities that are carried out under flexible and engaging manner. The sample consisted of ninety-eight students from proficiency level -104. The data of the study was collected using a questionnaire to identify students' level of satisfaction. The results revealed that students' satisfaction was apparent as their positive responses outweighed their negative responses mainly in terms of richness of learning resources, opportunity to interact in foreign language, appropriateness and variety of content, and ease of using Blackboard®. Based on the results, the study recommends considering the positive assets and challenges to plan the future of both teaching and learning English language effectively. The study suggested several areas to be investigated in the future such as examining the motivational behavior of both the teachers and the students and finding out the factors that will affect the environment of BL in EFL.
\end{abstract}

Keywords: blended learning, students's satisfaction, Blackboard, EFL, Saudi context

\section{Introduction}

The rapid and continuing development of Information and Communication Technology (ICT) has contributed to the emergence of Technology-Enhanced Learning (TEL), where such technologies facilitate the exchange of information and the spread of knowledge beyond the boundaries of traditional classrooms. As educators move their teaching practices to online environments and start to adapt web technologies to enhance their teaching pedagogies, the need arises to test the feasibility and advantages of such transfer with regard to the students' learning styles, interests, and readiness to adopt such changes in pedagogical practices. There is a constant struggle for educators to create authentic learning environments. There is also the need for interactivity and collaboration between teachers and learners as well as among the learners themselves.

The institutions of higher education in the Kingdom of Saudi Arabia (KSA) have started to approach this massive transformation by rethinking their teaching pedagogies, experimenting with online learning approaches and teaching strategies, and renovating delivery models. The distance education model that has been introduced at most universities in $\mathrm{KSA}$ is now supplemented with BL models, which will contribute to enhancing these universities' e-learning offerings.

Blended Learning is an approach that utilizes both face-to-face (F2F) teaching practices as well as e-learning environments and tools. It is the bringing together of two worlds (Graham, 2006). Garrison and Kanuta (2004) remarked that BL promotes deep learning as well as it progressively impacts on learning outcomes, lowers attrition rates, and enhance learners' satisfaction (Dziuban, Hartman, \& Moskal, 2004). It is defined by Brew (2008) as "a means of integrating the online component with face-to face formats to create effective learning experiences" (p. 98). Yilmaz-Soylu (2008), states the concept of BL is: "the effective combination of different modes of delivery, models of teaching and styles of learning" (p. 26). In the researchers' view, BL practices increase the effectiveness of the teaching and learning processes, thus it enhances learning beyond what might be 
accomplished with traditional learning and teaching practices. Lyons and Evans (2013) define BL as a "teaching model that incorporates technology while retaining the F2F element" (p. 43). For instance, BL incorporates technologies such as podcasts, lecture capture, online chat, and discussion boards. These kinds of tools are offered by the learning management system such as, Blackboard $\AA$. According to Lyons and Evans (2013) and Jonson (2011), the use of such technologies is perceived to enhance students' engagement in learning.

Although, BL has generated a certain amount of "buzz" in the community of learning and teaching as an improvement over traditional education, there is still a lack of clarity of the framework employed (Kerres \& Witt, 2003). The theoretical framework of $\mathrm{BL}$ in undergraduate education is quite broad. Factors relevant to formulating a theoretical framework include learners' motivation, style, and autonomy.

\subsection{Statement of a Problem}

A BL model offers wide varieties of tools for instructors and students to exchange and widen their knowledge as well as to interact and collaborate outside the regular classrooms. In EFL classrooms, where there is a recognized need for changing teaching practices, a BL model can be adopted to enhance students' interactions in English. Higher Education institutions offering EFL or English a Second Language (ESL) courses to non-native speakers of English have started to implement such a model. Ideally, BL context incorporates a Learning Management

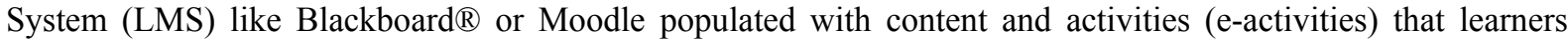
access and engage with instructors (e-tutors) who monitor students' interactions and collaborative activities and use the LMS's tools to facilitate students' learning.

The recent implementation of a robust LMS, Blackboard ${ }^{\circledR}$, at King Abdulaziz University (KAU), has motivated the researchers to examine its potential for introducing a BL model into EFL classes offered to Preparatory Year Program (PYP) students, who take up to sixteen hours of intensive English courses in four levels. The effectiveness of the proposed BL model depends significantly on the supplementary online component; hence the focus will be centered on how supplementary materials of the course can enhance students' performance and whether or not BL contributes to their overall satisfaction. In order to create a successful blended learning environment, the teacher's role, the students' role, and the quality of the course outline and materials, need to be considered. However, in this study, the researchers aim to see the effectiveness of using Blackboard on students' satisfaction.

The traditional, F2F model of learning used in teaching English as a foreign language at Saudi universities lacks effective utilization of multimodality, which requires effort on the part of the language instructor, especially when considering design and delivery issues. Multimodality means mixed use of various forms of content: images, texts, videos, audios, and so on. It is used to introduce a language concept, for example. Interactivity and collaboration are also scarce in the traditional face-to-face classroom. Designing rich interactive, collaborative, and multimodal experiences and delivering them within a traditional setting is a challenging task (Singh, 2003). Considering the BL model in a language course introduced via an LMS will simulate a classroom setting, as activities are carried out under the guidance of the instructor but in a more flexible and engaging manner. They also provide the learners with the opportunity to be exposed to the language and interaction which is not possible in the traditional classroom.

The study aims to identify the effect of BL model on students' satisfaction with the learning experience. Therefore, it attempts to answer the following research question:

How effective is the utilization of the supplementary materials on Blackboard ${ }^{\circledR}$ in leading up to EFL students' satisfaction with their learning experience?

\section{Literature Review}

Associated with the prevalence of BL is the theoretical framework of constructivism (Sherry, 1996, as cited in Heinze, 2008). The basic belief of the constructivists is that learning is a building-block-based process, in which certain stages must be dealt with first before moving on to the next stages and in which the learner is not a passive recipient, but rather, has an active role in the contribution of knowledge. Constructivism concerns these factors: "a) the roles of the learner and the teacher and b) the acknowledgement that learning is a socially and culturally determined activity" (Shepard, 2000, as cited in Heinze, 2008, p. 20). The constructivist view suggests that it is the 'facilitation' of learning that is important and hence the role of the teacher is changed to that of guide. Accordingly, the term constructivism refers to the idea that learners construct knowledge and meaning for themselves either individually or socially to learn. The emphasis of constructivism theory is on the process of learning. As Laurillard (2002) argues, it is about actively building learners' skills and knowledge. Similarly, Duffy and Cunningham (1996) state that: "knowledge comes from an active process of constructing rather than 
acquisition and instruction should support that construction rather than communicating knowledge" (as cited in Heinze, 2008, p. 204).

Piaget, a Swiss psychologist and one of the primary investigators within the constructivism framework, define it as a theory that endeavors to describe knowledge and how it is acquired (Nguyen, 2011). In an educational context, constructivism approaches learning through student-centered, project-based or problem-based, collaborative, cooperative, transformative and authentic, critical, interactive and collaborative activities. (Brooks \& Brooks, 1993; Fosnot, 1996; Gagné, 2005; Nguyen, 2011). It affirms that learning involves situation specific, social, and collaborative activities in which the learners are responsible for constructing their own knowledge by examining concepts based on their prior knowledge and experience (Bruner, 1996). Knowledge is constructed as a result of existing characteristics of a learner, such as their previous knowledge, stage of cognitive development, cultural background and personal history; also, their ability to interpret new information or experience and adapt it to their existing mental representation (Buner, 1960, as cited in Nguyen, 2011, pp. 10-11). The claim about BL is that students construct their knowledge through involvement with the context of education: a personalized learning experience.

The incorporation of online learning as virtual learning environment with face-to-face learning aims to maximize student-learning opportunities. It does so by offering access to supplementary materials that enhance learning and, by being continuously accessible, overcome time and space boundaries (Aliweh, 2011). Harvey, Plimmer, Moon, and Geall (1997) believe that learners are more likely to be satisfied with their overall educational experiences when the following areas are sensitively examined and planned for: "learner characteristics, technology, learning engagement, interaction and instruction" (as cited in Chang, 2011, p. 33). The current study will survey students' satisfaction about the learning experience in term of learner characteristics, technology and learning engagement. The following variables: learners' independence (Katz, 2002), age (Richardson \& Long, 2003), student autonomy (Bray, Aoki, \& Dlugosh, 2008), and online learning experiences (Rodriguez, Oms, Montanez, \& Yan, 2005) are learner characteristics found to contribute to satisfaction in e-Learning (as cited in Chang, 2011, pp. 34-35). Bray, Aoki and Dlugosh (2008) identify other factors that, increase student satisfaction: specifically, a student: "(1) could persevere in the face of distance learning challenges, (2) found computers easy to use, and (3) found it easy to interact with instructors" (as cited in Chang, 2011, pp. 34-35).

Students' experience during the use of technology plays an essential role in learner satisfaction. Research has shown that learners are more satisfied if they have positive course experiences, for example, flexibility in terms of time and geography (as cited in Chang, 2011). Students' engagement in the virtual environment happens because of their satisfaction (Chang, 2011). Richardson and Long (2003) claim that "student satisfaction is directly related to some aspects of academic practice and quality, which include communication, institutional affiliation, learning materials, relations with tutors, and tutorial pace" (p. 240). They state, "The attributes of quality academics include appropriate assessment, generic skills, good materials, and student choice" (p. 240). Moreover, Schumm, Webb, Turek, Jones, and Ballard (2006) find that satisfaction with critical thinking appeared to be the most important predictor variable. Along with that are instruction, overall training, and usefulness or relevance of training (Chang, 2011).

Likewise, the study of Kobayashi and Little (2011), conducted in the Japanese EFL context, reveals that the proficiency level of students affects their attitudes towards learning and the interface in using Computer Assisted Language Learning (CALL) courseware. BL may pose serious challenges for students and demand a greater deal of use. As such, experimental research should examine students' "comfort and satisfaction with online environment" (Hura, 2007, p. 731, as cited in Aliweh, 2011, p. 82). Student satisfaction can be promoted if the students' performances becomes more efficient and if they are taught in a way to which they can easily relate. In contrast, if students are taught in a way that does not fulfill their interests and needs, their performances change, and attitudes might not be positive (Aliweh, 2011). The findings of Pena and Yeung (2010) assured that regardless of the competence of students in using technology, students tend to be more satisfied with the F2F learning mode. It is found that students of business courses show positive attitudes to the Information and Communication Technology (ICT) based learning process. Osyerby (2012) also, finds that students preferred lectures with step-by-step instructions. Moreover, there were negative attitudes towards group work and formal communication. It seems students' satisfaction is highly affected by students' attitude, performance, and needs in different BL environments that includes use of technology in the regular educational context. It is essential to note that there are some factors that play a role in BL environment. The factors are not mainly related to enhancing and achieving students' satisfaction. They are some that have impact on achieving successful BL environment. Al-Busaidi and Al-Shihi (2012) point to individual characteristics, LMS characteristics, 
organizational characteristics. Similarly, the factors involve content and learning experience (Mitchell \& Honore, 2007).

\section{Methodology}

This research is considered empirical due to the fact that it used quantitative methodological approach that produces data through experiment as positivists have assumed (Carr \& Kemmis, 1986; Mackenzie \& Knipe, 2006, as cited in Assalahi, 2015). Similarly, it encompasses empirical approach to yield data from social experiment (McGregor \& Murnane, 2010). It catalyzes to generate a hypothesis and testing. Hence, the study provides clear clarification about the effect of BL in EFL context and definite low subjectivities (Cohen \& Crabtree, 2006; Ryan, n.d) from the researchers. Consequently, the impact of BL on students' satisfaction would be explored through adopting the concepts of positivist approach.

True-experimental design would be the suitable design for the nature of this study, to quantify the cause and effect relationship among the dependent (predictor) and independent (outcome) variables (Sousa, Driessnack \& Mendes, 2007). To comply true-experimental design, the researchers assigned two research groups by selecting Posttest Only Control Group, which is a type of experimental design. Students' satisfaction was examined throughout the students who tackled the intervention.

The implementation of using the LMS- Blackboard ${ }^{\circledR}$ preceded with signing the users in Blackboard ${ }^{\circledR}$ and building the content. The establishment of using Blackboard $\AA$ was attained through three stages - initial stage, implementation stage, ending stage, which are clarified in the following with the encountered challenges. Respectively, the strategies of building the content are presented.

\subsection{Participants}

The population of the study consisted of EFL learners, who study English as a foreign language (EFL) during the preparatory years at ELI in KAU. The population referred to all the applicants of KAU who were designated specific English proficiency levels based on their performances in the placement test.

\subsection{The Sample of Study}

The sample is a portion of the population or the experimentally accessible population as Fred and Perry (2005) called it; were taken from already existed classrooms of the 104 English proficiency level with random selection protocol for experimental group. The researcher randomly selected two classes of 104 proficiency level students and assigned them for experimental purposes. The two classes dealt with the intervention at one time by native English teachers. The participants were 48 students, without considering two students who dropped out the course. The experimental group had 48 students, without considering two students who dropped out the course. As research participants were assigned, the researcher clarified the research purpose for research ethical approval.

\subsection{Research Instruments}

The study depended on a cross sectional, quantitative data that was obtained at the end of implementing the LMS (Blackboard (®). The data was gathered from the questionnaire which was allocated to survey the satisfaction of the experimental group. The questionnaire asked about the students' satisfaction with BL mode. It was built throughout building the theoretical framework and previous studies as well as previous surveys that were in the literature such as (Aliweh, 2011; Kobayashi \& Little, 2011; Pena, \& Yeung, 2010), and from the verification of advisors who reviewed the questionnaire in its first draft. It consisted of 28 statements that examined the degree

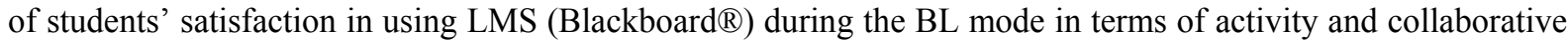
work, richness of learning resource, interaction and ease of use. The statements were measured by using Likert scale responses to specify the degree of students' satisfaction on a 5-point scale (" 1 " extremely unsatisfied, " 2 " not satisfied, " 3 " not sure, " 4 " satisfied, " 5 " extremely satisfied). It is designed in closed form to promote the accuracy of the results and reduce error of variation (Wilson \& McLean, 1994). It was translated into Arabic language to ensure its simplicity and clarity for the respondents, since Arabic is the native language for all the participants and some participants may not be proficient in English. The questionnaire was distributed at the end of the module, particularly, on the day of the final speaking exam; to ensure that participants are present in order to gain maximum number of responses. The responses were 47 from 48 students. The validity of the questionnaire was improved through the consultation of an expertise assistant professor in the fields of education, Teaching English to Speakers of Other Languages (TESOL) and educational technology. The reliability of the questionnaire was established by calculating the Cronbach's alpha coefficient which gave a value of 0.924 which indicated a high reliable scale. 


\subsection{Instructional Stages of Using LMS- Backboard ${ }^{\circledR}$}

The implementation of using the LMS- Blackboard ${ }^{\circledR}$ preceded with signing the users in Blackboard $\AA$ and building the content. The establishment of using the Blackboard ${ }^{\circledR}$ was attained through three stages - initial stage, implementation stage and ending stage. The strategies of building the content are presented respectively.

\subsubsection{Stages of Implementation}

The initial stage included assigning two voluntary teachers who would apply the study in ELI classes of level 104 , and preparing the teachers to the use of Blackboard $\AA$. Thus, introductory meeting with the e-learning development center in deanship of e-learning and distance learning was conducted on the $5^{\text {th }}$ of January, 2015 to converse the different practice of Blackboard ${ }^{\circledR}$. After that, teachers joined Blackboard workshop that explained basic utilization of Blackboard ${ }^{\circledR}$ tools. The workshop took place on the $9^{\text {th }}$ of February, 2015 for two days at the center for teaching and learning development.

After setting and preparing the participated teachers, the researcher moved to the next stage, which was the implementation of Blackboard $\mathbb{R}$. The participated teachers were assigned to 104 classes randomly to use Blackboard ${ }^{\circledR}$. Initially, students were familiarized to the concept of the study for ethical research purpose and to sign the consent form. Then, lab sessions were scheduled for two hours and thirty minutes each week for the whole module which was six weeks of teaching. By allocating weekly lab sessions, students will access the content and get guidance and support, which will encourage them to use it off-campus. During the first lab session, students were introduced to use blackboard as research purpose required, in which they gained the benefits of using the supplementary content by contribution in the tasks, complete the quizzes, practices of online learning resources, considering the course announcement and guidance. Besides, they were given a handout, which was created by the deanship of E-learning at KAU to clarify the use of Blackboard ${ }^{\mathbb{R}}$. It was concluded by examining the students' satisfaction through allotting the questionnaire concerning experimenting

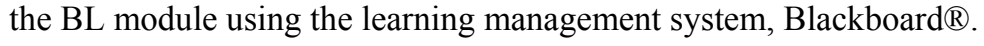

\subsubsection{The Description of Intervention- Blackboard}

The contents of Blackboard ${ }^{\circledR}$ were mainly developed in a way that supplements the course objectives and the pacing schedule guide of the 104 level according to ELI's plans of teaching. The teachers, who were willing to experiment the study in their classes, built the content and shared. The presentation of the contents on Blackboard ${ }^{\circledR}$ were divided into six sections and each section represented one week of the six teaching weeks of the 104 level. For each week, students were having supplementary materials that enhanced their knowledge, in a way that did not contrast with the textbook content. Weekly, students practiced tasks that were made available online such as the practice of grammar, vocabulary and collaborative activities. The supplementary materials included quizzes for each unit, mid-module practice, and writing guidelines and tips. Certain tools of Blackboard ${ }^{\circledR}$ system were utilized, which were activities, assignment, board discussion, creating quizzes and announcement boards.

\section{Results}

The results of the data collection are presented from one main resource: students' responses to the post questionnaire. It is assumed that BL module will lead to a greater EFL students' satisfaction with the BL experience. The descriptive statistics of frequencies, percentage and mode were calculated in order to find the results of students' responses in the questionnaire. Additionally, it is worth mentioning here that the percentages of the values of agreements were combined, as they are considered to reveal substantial results. 


\subsection{Activities and Collaborative Work}

Table 2. Students' satisfaction about the use of supplementary materials in terms of activities and collaborative work. (E.UNS. Extremely unsatisfied, NS. Unsatisfied, NS. Not sure, S. satisfied, E.S. Extremely satisfied)

\begin{tabular}{|c|c|c|c|c|c|c|c|c|}
\hline \multicolumn{9}{|l|}{ Activities and Collaborative work } \\
\hline \multicolumn{2}{|l|}{ Statements } & E.UN & UNS. & NS & S. & E.S. & Total & Mode \\
\hline \multirow{3}{*}{$\begin{array}{l}\text { 1. The supplementary activities } \\
\text { in BB are useful }\end{array}$} & Freq. & 2 & 5 & 4 & 29 & 7 & 46 & \multirow[t]{3}{*}{ Agree (4) } \\
\hline & \multirow[t]{2}{*}{$\%$} & 4.2 & 10.4 & \multirow[t]{2}{*}{$8.3 \%$} & 60.4 & 14.6 & \multirow[t]{2}{*}{97.9} & \\
\hline & & \multicolumn{2}{|c|}{$14.6 \%$} & & \multicolumn{2}{|l|}{$75 \%$} & & \\
\hline \multirow{3}{*}{$\begin{array}{l}\text { 2. The supplementary activities } \\
\text { have increased my motivation to } \\
\text { learn }\end{array}$} & Freq. & 4 & 9 & 14 & 16 & 4 & 47 & \multirow[t]{3}{*}{ Agree (4) } \\
\hline & \multirow[t]{2}{*}{$\%$} & 8.3 & 18.8 & \multirow{2}{*}{$\begin{array}{l}29.2 \\
\%\end{array}$} & 33.3 & 8.3 & \multirow[t]{2}{*}{97.9} & \\
\hline & & $27.1 \%$ & & & $41.6^{\circ}$ & & & \\
\hline \multirow{3}{*}{$\begin{array}{l}\text { 3. The supplementary activities } \\
\text { will enhance my final } \\
\text { achievement. }\end{array}$} & Freq. & 2 & 1 & 17 & 22 & 5 & 47 & \multirow[t]{3}{*}{ Agree (4) } \\
\hline & \multirow[t]{2}{*}{$\%$} & 4.2 & 2.1 & \multirow{2}{*}{$\begin{array}{l}35.4 \\
\%\end{array}$} & 45.8 & 10.4 & \multirow[t]{2}{*}{97.9} & \\
\hline & & \multicolumn{2}{|l|}{$6.3 \%$} & & \multicolumn{2}{|c|}{$56.2 \%$} & & \\
\hline \multirow{3}{*}{$\begin{array}{l}\text { 4. Using BB for learning has } \\
\text { encouraged me to try it again. }\end{array}$} & Freq. & 12 & 11 & 10 & 8 & 6 & 48 & \multirow{3}{*}{$\begin{array}{l}\text { Extremely } \\
\text { disagree } \\
\text { (1) }\end{array}$} \\
\hline & \multirow[t]{2}{*}{$\%$} & 25.0 & 22.9 & \multirow{2}{*}{$\begin{array}{l}20.8 \\
\%\end{array}$} & 16.7 & 12.5 & \multirow[t]{2}{*}{97.9} & \\
\hline & & $47.9 \%$ & & & $29.2^{\circ}$ & & & \\
\hline \multirow{3}{*}{$\begin{array}{l}\text { 5. BB makes language learning } \\
\text { more enjoyable }\end{array}$} & Freq. & 5 & 12 & 13 & 15 & 2 & 47 & \multirow[t]{3}{*}{ Agree (4) } \\
\hline & \multirow[t]{2}{*}{$\%$} & 10.4 & 25.0 & \multirow{2}{*}{$\begin{array}{l}27.1 \\
\%\end{array}$} & 31.3 & 4.2 & \multirow[t]{2}{*}{98} & \\
\hline & & $35.4 \%$ & & & $35.5^{\circ}$ & & & \\
\hline \multirow{3}{*}{$\begin{array}{l}\text { 6. I prefer studying with using } \\
\text { BB }\end{array}$} & Freq. & 13 & 15 & 11 & 6 & 2 & 47 & \multirow{3}{*}{$\begin{array}{l}\text { Disagree } \\
\text { (2) }\end{array}$} \\
\hline & $\%$ & 27.1 & 31.3 & \multirow{2}{*}{$\begin{array}{l}22.9 \\
\%\end{array}$} & 12.5 & 4.2 & \multirow[t]{2}{*}{98} & \\
\hline & & $58.4 \%$ & & & $16.7^{\circ}$ & & & \\
\hline
\end{tabular}

The data in Table 2 highlights the level of satisfaction in terms of activities and collaborative work. It is apparent that statements 1, 2, 3 and 5 gained mostly a value of 4 which represents the highest percentage of students' agreement with the statement.

The percentages were between $75 \%$ and $35.5 \%$ for the statements that showed that the activities were useful, had increased their motivation and enjoyment in learning the language and probably enhanced their achievement. However, it is apparent from statement 5 that the result was not truly significant. It showed $35.5 \%$ and $35.4 \%$ of students' agreement and disagreement respectively, and $27.1 \%$ of their uncertainty about the enjoyment of using BL. Similarly, statements 4 and 6 may be considered negative. However, responses to statements 4 and 6 , which asked the students about their inclination to use Blackboard $\AA$ for learning in the future, revealed a wide variety of opinions, which ranged from values 5 to 1 . However, the highest percentage indicated they do not prefer to use Blackboard $\AA$, so they disagreed to experiment it again as the results illustrated $47.9 \%$ in statement 4 and $58.4 \%$ in statement 6 . 


\subsection{Richness of Learning Resources}

Table 3. Students' satisfaction regarding the use of supplementary materials in terms of richness of learning resources

\begin{tabular}{|c|c|c|c|c|c|c|c|c|}
\hline \multicolumn{9}{|l|}{ Richness of learning resource } \\
\hline \multicolumn{2}{|l|}{ Statements } & E.UNS & UNS. & NS & S. & E.S. & Total & Mode \\
\hline \multirow{3}{*}{$\begin{array}{l}7 . \quad \text { The use of multimedia } \\
\text { makes language learning } \\
\text { better }\end{array}$} & Freq. & 1 & 1 & 5 & 30 & 10 & 47 & \multirow{3}{*}{$\begin{array}{l}\text { Agree } \\
\text { (4) }\end{array}$} \\
\hline & \multirow[t]{2}{*}{$\%$} & 2.1 & 2.1 & \multirow[t]{2}{*}{$10.4 \%$} & 62.5 & 20.8 & \multirow[t]{2}{*}{97.9} & \\
\hline & & \multicolumn{2}{|l|}{$4.2 \%$} & & \multicolumn{2}{|c|}{$83.3 \%$} & & \\
\hline \multirow{3}{*}{$\begin{array}{l}\text { 8. The use of BB fulfills } \\
\text { my requirements in using } \\
\text { technology for learning. }\end{array}$} & Freq. & 1 & 2 & 12 & 25 & 7 & 47 & \multirow{3}{*}{$\begin{array}{l}\text { Agree } \\
\text { (4) }\end{array}$} \\
\hline & $\%$ & 2.1 & 4.1 & \multirow[t]{2}{*}{$25.0 \%$} & 52.1 & 14.6 & \multirow[t]{2}{*}{97.9} & \\
\hline & & $6.2 \%$ & & & $66.7 \%$ & & & \\
\hline \multirow{3}{*}{$\begin{array}{l}\text { 9. Supplementary contents } \\
\text { offer chances to improve my } \\
\text { linguistics competence }\end{array}$} & Freq. & 1 & 3 & 17 & 24 & 2 & 47 & \multirow{3}{*}{$\begin{array}{l}\text { Agree } \\
\text { (4) }\end{array}$} \\
\hline & $\%$ & 2.1 & 6.3 & \multirow[t]{2}{*}{$35.4 \%$} & 50.0 & 4.1 & \multirow[t]{2}{*}{97.9} & \\
\hline & & $8.4 \%$ & & & $54.1 \%$ & & & \\
\hline \multirow{3}{*}{$\begin{array}{l}\text { 10. Supplementary contents } \\
\text { do not contrast with the } \\
\text { textbook }\end{array}$} & Freq. & 1 & 1 & 11 & 24 & 10 & 47 & \multirow{3}{*}{$\begin{array}{l}\text { Agree } \\
\text { (4) }\end{array}$} \\
\hline & $\%$ & 2.1 & 2.1 & \multirow[t]{2}{*}{$22.9 \%$} & 50.0 & 20.8 & \multirow[t]{2}{*}{97.9} & \\
\hline & & $4.2 \%$ & & & $70.8 \%$ & & & \\
\hline \multirow{3}{*}{$\begin{array}{l}\text { 11. Supplementary contents } \\
\text { offer good practice of } \\
\text { English grammar }\end{array}$} & Freq. & 2 & 4 & 11 & 25 & 5 & 47 & \multirow{3}{*}{$\begin{array}{l}\text { Agree } \\
\text { (4) }\end{array}$} \\
\hline & $\%$ & 4.2 & 8.3 & \multirow[t]{2}{*}{$22.9 \%$} & 52.1 & 10.4 & \multirow[t]{2}{*}{97.9} & \\
\hline & & $12.5 \%$ & & & $62.5^{\circ}$ & & & \\
\hline \multirow{3}{*}{$\begin{array}{l}\text { 12. Supplementary contents } \\
\text { help in understanding the } \\
\text { vocabulary }\end{array}$} & Freq. & 1 & 3 & 10 & 29 & 4 & 47 & \multirow{3}{*}{$\begin{array}{l}\text { Agree } \\
\text { (4) }\end{array}$} \\
\hline & $\%$ & 2.1 & 6.3 & \multirow[t]{2}{*}{$20.8 \%$} & 60.4 & 8.3 & \multirow[t]{2}{*}{97.9} & \\
\hline & & $8.4 \%$ & & & $68.7 \%$ & & & \\
\hline \multirow{3}{*}{$\begin{array}{l}\text { 13. Supplementary contents } \\
\text { assist me to use the } \\
\text { vocabulary }\end{array}$} & Freq. & 1 & 6 & 12 & 22 & 6 & 47 & \multirow{3}{*}{$\begin{array}{l}\text { Agree } \\
\text { (4) }\end{array}$} \\
\hline & $\%$ & 2.1 & 12.5 & \multirow[t]{2}{*}{$25.0 \%$} & 45.8 & 12.5 & \multirow[t]{2}{*}{97.8} & \\
\hline & & $14.5 \%$ & & & $58.3 \%$ & & & \\
\hline
\end{tabular}

With regards to the second aspect, the collaborative work, the majority of responses showed students' agreement in all of the seven statements as illustrated in Table 3. The percentages of the combined values of agree were between $83.3 \%$ and $54.1 \%$. In statements $7,8,10,11,12$ and 13 , the figures were above $55 \%$, while statement 9's figure was $54.1 \%$.

The repeated frequencies of students' satisfaction about the richness of learning resources are considerably sharp

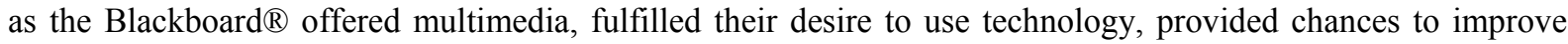
their linguistics competence, practiced English grammar, helped in understanding and using of the vocabularies in a way that did not contrast with the textbook. 


\subsection{Students' Interaction}

Table 4. Students' satisfaction about the use of supplementary materials in terms of interaction

\begin{tabular}{|c|c|c|c|c|c|c|c|c|}
\hline \multicolumn{9}{|l|}{ Interaction } \\
\hline \multicolumn{2}{|l|}{ Statements } & E.UNS & UNS. & NS & S. & E.S & Total & Mode \\
\hline \multirow{3}{*}{$\begin{array}{l}\text { 14. Supplementary contents } \\
\text { in BB will improve my } \\
\text { interaction in } \text { English } \\
\text { language }\end{array}$} & Freq. & - & 3 & 11 & 23 & 10 & 47 & \multirow{3}{*}{$\begin{array}{l}\text { Agree } \\
\text { (4) }\end{array}$} \\
\hline & \multirow[t]{2}{*}{$\%$} & - & 6.3 & \multirow[t]{2}{*}{$22.9 \%$} & 47.9 & 20.8 & \multirow[t]{2}{*}{97.9} & \\
\hline & & \multicolumn{2}{|l|}{$6.3 \%$} & & \multicolumn{2}{|c|}{$68.7 \%$} & & \\
\hline \multirow{3}{*}{$\begin{array}{l}\text { 15. Supplementary contents } \\
\text { increase my contribution in } \\
\text { the English classroom. }\end{array}$} & Freq. & - & 4 & 17 & 21 & 5 & 47 & \multirow{3}{*}{$\begin{array}{l}\text { Agree } \\
(4)\end{array}$} \\
\hline & \multirow[t]{2}{*}{$\%$} & - & 8.3 & \multirow[t]{2}{*}{$35.4 \%$} & 43.8 & 10.4 & \multirow[t]{2}{*}{97.9} & \\
\hline & & $8.3 \%$ & & & 54.2 & & & \\
\hline \multirow{3}{*}{$\begin{array}{l}\text { 16. Supplementary contents } \\
\text { in BB improve my written } \\
\text { interaction. }\end{array}$} & Freq. & - & 1 & 10 & 23 & 13 & 47 & \multirow{3}{*}{$\begin{array}{l}\text { Agree } \\
\text { (4) }\end{array}$} \\
\hline & \multirow[t]{2}{*}{$\%$} & - & 2.1 & \multirow[t]{2}{*}{$20.8 \%$} & 47.9 & 27.1 & \multirow[t]{2}{*}{97.9} & \\
\hline & & $2.1 \%$ & & & $75 \%$ & & & \\
\hline \multirow{3}{*}{$\begin{array}{l}\text { 17. Supplementary contents } \\
\text { in BB improve my reading } \\
\text { ability }\end{array}$} & Freq. & - & 3 & 17 & 15 & 12 & 47 & \multirow{3}{*}{$\begin{array}{l}\text { Not } \\
\text { sure (3) }\end{array}$} \\
\hline & \multirow[t]{2}{*}{$\%$} & - & 6.3 & \multirow[t]{2}{*}{$35.4 \%$} & 31.3 & 25.0 & \multirow[t]{2}{*}{97.9} & \\
\hline & & $6.3 \%$ & & & 56.3 & & & \\
\hline \multirow{3}{*}{$\begin{array}{l}\text { 18. Supplementary contents } \\
\text { in BB develop my listening } \\
\text { skills. }\end{array}$} & Freq. & - & 1 & 12 & 25 & 9 & 47 & \multirow{3}{*}{$\begin{array}{l}\text { Agree } \\
\text { (4) }\end{array}$} \\
\hline & \multirow[t]{2}{*}{$\%$} & - & 2.1 & \multirow[t]{2}{*}{$25.0 \%$} & 52 & 18.8 & \multirow[t]{2}{*}{97.9} & \\
\hline & & $2.1 \%$ & & & 70.8 & & & \\
\hline \multirow{3}{*}{$\begin{array}{l}\text { 19. Supplementary contents } \\
\text { in BB are useful for practicing } \\
\text { the language. }\end{array}$} & Freq. & - & 6 & 14 & 21 & 6 & 47 & \multirow{3}{*}{$\begin{array}{l}\text { Agree } \\
(4)\end{array}$} \\
\hline & \multirow[t]{2}{*}{$\%$} & - & 12.5 & \multirow[t]{2}{*}{$29.1 \%$} & 43.8 & 12.5 & \multirow[t]{2}{*}{97.9} & \\
\hline & & \multicolumn{2}{|l|}{$12.5 \%$} & & 56.3 & & & \\
\hline
\end{tabular}

Table 4 presents the figures for the students' satisfaction about the interaction in BL using the learning management system, Blackboard ${ }^{\circledR}$. Based upon the results from the computed data, the highest responses were in items 14,16 , and 18 in which the participants agreed that supplementary contents improved their interaction with $68.7 \%$, written interaction with $75 \%$ as well as developing their listening skills with $70.8 \%$. In statements, 15,17 and 19, the respondents were inconsistence as it is noticed from the frequencies in Table 4, particularly, if the frequencies of the values of the 'not sure' and agree are taken into considerations.

However, the combined percentages of students' agreement appeared to be more than $50 \%$ in all the statements. As statements, 15 revealed $54.2 \%, 17$ revealed $56.3 \%, 19$ revealed $56.3 \%$, respectively. Yet, they seemed not highly sharp as statements 14,16 and 18 , since oral class contributions and oral language practices may decrease while using technology. Meanwhile, in BL, students are engaged with computers, or, they may collaboratively work on a computer. However, reading skills are unlikely to be definitely affected in BL mode, which may be expected as it is considered a receptive skill.

By focusing on the modes in Table 4, it is reasonable to claim that students were satisfied with BL as six statements out of seven were of 'agreed on'. This is clearly a reminder that this aspect is to some extent similar to the previous one, which was illustrated in table 3 since creating opportunities to interact, is mainly handled by the teacher attempts in using the environment of BL as a place where students interact orally, or with written discourses and employ second language skills in the interaction. 


\subsection{Ease of Using Blackboard}

Table 5. Students' satisfaction about the use of supplementary materials in LMS, Blackboard $\AA$, in terms of ease of use

\begin{tabular}{|c|c|c|c|c|c|c|c|c|}
\hline \multicolumn{9}{|l|}{ Ease of use } \\
\hline \multicolumn{2}{|l|}{ Statements } & E.UNS & UNS. & NS & S. & E.S. & Total & Mode \\
\hline \multirow[t]{3}{*}{ 20. BB is easy to use. } & Freq. & 3 & 7 & 11 & 19 & 7 & 47 & \multirow[t]{3}{*}{ Agree (4) } \\
\hline & \multirow[t]{2}{*}{$\%$} & 6.3 & 14.6 & \multirow[t]{2}{*}{$22.9 \%$} & 39.5 & 14.6 & \multirow[t]{2}{*}{97.9} & \\
\hline & & \multicolumn{2}{|l|}{$20.9 \%$} & & \multicolumn{2}{|c|}{$54.1 \%$} & & \\
\hline \multirow{3}{*}{$\begin{array}{l}\text { 21. Contents in BB are } \\
\text { clear and organized. }\end{array}$} & Freq. & 4 & 5 & 8 & 22 & 8 & 47 & \multirow[t]{3}{*}{ Agree (4) } \\
\hline & \multirow[t]{2}{*}{$\%$} & 8.3 & 10.4 & \multirow[t]{2}{*}{$16.7 \%$} & 45.8 & 16.7 & \multirow[t]{2}{*}{97.9} & \\
\hline & & \multicolumn{2}{|l|}{$18.7 \%$} & & \multicolumn{2}{|c|}{$62.5 \%$} & & \\
\hline \multirow{3}{*}{$\begin{array}{l}\text { 22. Lab sessions help in } \\
\text { using BB. }\end{array}$} & Freq. & - & 3 & 9 & 18 & 17 & 47 & \multirow[t]{3}{*}{ Agree (4) } \\
\hline & \multirow[t]{2}{*}{$\%$} & - & 6.3 & \multirow[t]{2}{*}{$18.8 \%$} & 37.5 & 35.3 & \multirow[t]{2}{*}{97.9} & \\
\hline & & \multicolumn{2}{|l|}{$6.3 \%$} & & \multicolumn{2}{|c|}{$72.8 \%$} & & \\
\hline \multirow{3}{*}{$\begin{array}{l}\text { 23. Prior experience in } \\
\text { using technology helps in } \\
\text { using BB. }\end{array}$} & Freq. & - & 5 & 7 & 17 & 18 & 47 & \multirow{3}{*}{$\begin{array}{l}\text { Strongly } \\
\text { agree (5) }\end{array}$} \\
\hline & $\%$ & - & 10.4 & \multirow[t]{2}{*}{$14.6 \%$} & 35.4 & 37.5 & \multirow[t]{2}{*}{97.9} & \\
\hline & & $10.4 \%$ & & & $72.9^{\circ}$ & & & \\
\hline \multirow{3}{*}{$\begin{array}{l}\text { 24. IT services help me to } \\
\text { identify the use BB system. }\end{array}$} & Freq. & - & 3 & 15 & 24 & 5 & 47 & \multirow[t]{3}{*}{ Agree (4) } \\
\hline & $\%$ & - & 6.3 & \multirow[t]{2}{*}{$31.3 \%$} & 49.9 & 10.4 & 97.9 & \\
\hline & & $6.3 \%$ & & & $60.3^{\circ}$ & & & \\
\hline 25. I feel anxious while & Freq. & 4 & 16 & 13 & 9 & 5 & 47 & Disagree(2) \\
\hline using BB for learning the & $\%$ & 8.3 & 33.3 & $27.1 \%$ & 18.8 & 10.4 & 97.9 & \\
\hline & & $41.6 \%$ & & & $29.2^{0}$ & & & \\
\hline 26. Trial quizzes in $\mathrm{BB}$ & Freq. & 2 & 6 & 13 & 16 & 10 & 47 & Agree (4) \\
\hline help to prepare and study for & $\%$ & 4.2 & 12.5 & $27.1 \%$ & 33.3 & 20.8 & 97.9 & \\
\hline & & $16.7 \%$ & & & $54.1^{\circ}$ & & & \\
\hline 27. Evaluation system in & Freq. & 2 & 7 & 15 & 12 & 11 & 47 & Not sure (3) \\
\hline methods of taking exams. & $\%$ & 4.2 & 14.6 & $31.3 \%$ & 25.0 & 22.8 & 97.9 & \\
\hline & & $18.8 \%$ & & & $47.8^{\circ}$ & & & \\
\hline 28. I can easily use the & Freq. & 2 & 7 & 12 & 17 & 9 & 47 & Agree (4) \\
\hline tools of BB. & $\%$ & 4.2 & 14.6 & $25.0 \%$ & 35.3 & 18.8 & 97.9 & \\
\hline & & $18.8 \%$ & & & $54.1^{\circ}$ & & & \\
\hline
\end{tabular}

Moving to the fifth table, the ease of using Blackboard ${ }^{\circledR}$ as LMS in BL mode was considered in the fourth aspect of the questionnaire. It is noticed from looking at the frequencies, that the students' responses were inconsistent. Besides, the mode represented four different values, which are: extremely agree, agree, not sure and disagree. The combined percentages displayed the level of students' satisfaction about Blackboard ${ }^{\circledR}$ as LMS and the values ranged from $72.9 \%$ to $41.6 \%$. The respondents revealed their satisfaction in statements $20,21,22,23$, 24,26 and 28 . Since the percentages appeared to be $54.1 \%, 62.5 \%, 72.8 \%, 72.9 \%, 60.3 \%, 54.1 \%, 54.1 \%$, respectively.

Regarding their responses on the ease of using Blackboard $\AA$, the clarity and organization of Blackboard $\AA$ presentation, lab sessions, and prior experience in using technology, IT services, trial quizzes and the ability to 


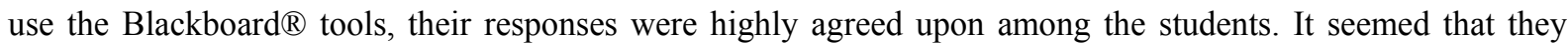
were satisfied about the overall use of Blackboard $\AA$, as statement 28 notes: "I can easily use the tools of Blackboard" and statement 20 notes: "Blackboard is easy to use" they both consolidate one another since they both revealed the same percentage of $54.1 \%$. This could be an evidence of the reliability of the students' satisfaction about using Blackboard®.

Students' disagreement in statement 25 about having anxiety while using Blackboard ${ }^{\circledR}$ was an indicator of their ability to deal with technology. It showed that there is internal factors like anxiety that may inhibit them in using Blackboard ${ }^{\circledR}$ as LMS. It also confirmed, that their disagreement about using LMS in future, which was presented in table 2, was illogical, since $53.3 \%$ claimed they were able to use the system. It sheds the light on the findings of Pena and Yeung (2010), in which students' competence in using technology did not affect students' attitude towards BL, as they prefer F2F learning mode. Regarding electronic exams in statement 27, participants indicated their uncertainty about the evaluation system as it presented from table 5, in the resultant calculation of the mode. However, the combined percentages of agreement in statement 27 could be considered low in comparison with the other statements in this respect. The notion here is that exam anxiety may exist as well as the technical difficulty, which is likely to occur. Thus, the students' uncertainty to adopt the evaluation of Blackboard ${ }^{\circledR}$ is expected.

\section{Discussion and Conclusion}

The rationale behind the high percentages of certain responses in statements 1,2,3 and 5, may stem from certain factors such as appropriateness, variety of activities in contents and forms, which lead to an increase in their satisfaction in using BL mode. Besides, the teacher's role might play a part in motivating the students to participate in Blackboard ${ }^{\circledR}$ as Marsha (2012) pointed out in his study. Nonetheless, students' discouragement to experience BL mode in the future might be due to the environment of using Blackboard ${ }^{\circledR}$. Similarly, it could be interpreted as a status of avoidance to use it in the future since it was conducted in a short module with no motivational sources such as grade, that could lead students to feel disinclined to use (as one of the female section teachers put it) even though, it may contribute to live classes and stimulate learners (Aycock, Garnham, \& Kaleta, 2002, as cited in Tao. et al., 2011). Although $75 \%$ of the students claimed that using the supplementary materials of BL were beneficial, $47.9 \%$ of them declared their discouragement and $58.4 \%$ expressed their reluctance to use it in future. This can indicate two important issues. The first issue is the lack of skills in dealing with BL mode, which includes time management, autonomous learning, or lack of teacher guidance. Furthermore, it means that students' perception concerning the BL should be enhanced.

Based on this evidence, Perters, Weinberg and Sarma (2009) assured that BL includes high rate of enjoyment and usefulness which were considerably clear in this present study. However, BL mode is perceived by some researchers to cause an increase in the study pressure and negative attitudes towards the task loads (Stepp-Greany, 2002; Gimeno Sanz, 2009; Bueno-Alastuey, 2009, as cited in Alastuey \& Lopez-Perez, 2014). Therefore, it might also be justified by considering the determent points of BL (Bueno-Alastuely, 2009; Burguess, 2003, as cited in Alastuey \& Lopez-Perez, 2014) that they consume a substantial amount of the learner's time as well as require the learner to be able to use technology. This ought to similarly be apparent in Pena and Yeung (2010), in which they argued that students' competence in using technology is not a major attraction, as they prefer the F2F learning mode. However, Bueno-Alastuey \& Lopez-Perez (2014) revealed in their study that the learners of English language and Spanish language found BL is both useful and the preferred mode.

The level of using BL affected the level of development, which revealed that the level of satisfaction is a percentage of students' self-evaluation, which appeared to be similar to what Aliweh (2011) suggested that students' satisfaction is promoted if they found the contents to be easy to relate to. Also, it serves as a reminder about the benefits of BL for language learner, as Alastuey and Lopez-Perez (2014) pointed out to the linguistics benefits and language skills gains (Beauvois, 1998, as cited in Alastuey \& Lopez-Perez, 2014) which assured the students' satisfaction in terms of interaction. Logically, the high number of students' agreements with regards to the richness of learning resources, is a reminder that the variety of contents and multimedia in LMS indicated its usefulness as Table 2 showed the figure to be $75 \%$ in statement one. Moreover, it is a reminder about teacher's awareness in offering the content that met most of the students' needs.

As mentioned previously, the quality of academic content and practice plays a direct role in the students' satisfaction (Richardson \& Long, 2003). Also, it was suggested by Murray (1999, as cited in Alastuey \& Lopez-Perez, 2014) that BL meets language learners' goals, enhance the learning process along with the online resources and overcome learning difficulties (Aycock, Garnham, \& Kaleta, 2002, as cited in Tao. et al., 2011), 
which seemed to be also agreed with in the current study since students revealed satisfaction about the learning resources in the online component of BL.

Based on these findings, it is plausible to agree with what Bray, Bray, Aoki and Dlugsoh (2008) stated, that students' satisfaction is found to be affected by the ease of using computers (as cited in Change, 2011). Furthermore, it was found in the present study that students' satisfaction about the electronic exam in Blackboard ${ }^{\circledR}$ were not clearly significant. It was concluded that there might be some external factors related to the environment of implementing Blackboard ${ }^{\circledR}$. First, it was concluded that the first experimental implementation of Blackboard ${ }^{\circledR}$ for supplementary purpose in ELI for onsite learners, the students' usage was not graded which highlights the role of external stimulation to secure the success of the BL environment. Second, this revealed some of the technical difficulties in the Blackboard ${ }^{\circledR}$ features, e.g. board discussion, that teacher overcame to create accessible and serviceable content (which is an anecdotal statement given by one of the teachers who experiment Blackboard at women's campus at the ELI). The participants, in the study of Kashghari and Asseel (2014), similarly reported technical difficulties in using Blackboard. Teachers reported as

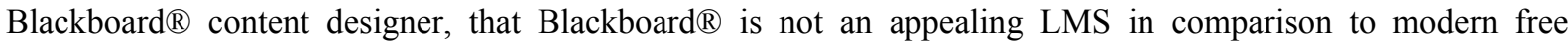
systems in regards of presentation and simplicity to use (which is an anecdotal statement given by one of the

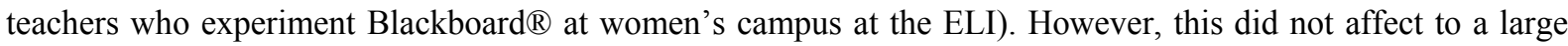
extent the students' satisfaction. In short, the utilization of the supplementary materials on Blackboard ${ }^{\circledR}$ led to the students' satisfaction in some aspects, as it was considerably noticed in the prior discussion. It is supposed to be mentioned, yet, that BL is not limited to the use of a particular tool of technology. As it could be any learning management system such as Moodle, or using web CT, CALL, internet, mobile learning, so on. However, as was elaborated before, that $\mathrm{BL}$ is about providing the innovative learning environment that works easily to increase the effectiveness of learning (Neumeier, 2005). It is important to note here that the low level of satisfaction may be a result of students' unwillingness to attempt using it in future and to adopt the evaluation system of Blackboard ${ }^{\circledR}$. It might be noticed from the learner's sense of independency and motivation (Lynch \& Dembo, 2004). Alternatively, Kobayashi and Little (2011) indicated that the level of students' proficiencies reflected on their attitude towards learning and interface in using the technology. It was suggested that Blackboard ${ }^{\circledR}$ was possible to be used for supplementary purposes. However, some of its features were not operating effectively, which may have led to the students' uncertainty to accept it as a tool for evaluation and assessment (which is an anecdotal statement given by one of the teachers who experiment Blackboard at women's campus at the ELI).

More significant findings that emerged from this study, were regarding the richness of the learning resources and the opportunity to interact in foreign language in Blackboard ${ }^{\circledR}$. The positive claim, which the data revealed, was the usefulness of using supplementary activities in Blackboard $\AA$. Precisely, it was found that the appropriateness, variety of activities in contents and forms have increased students' satisfaction. The quality and value of content fulfilled learners' needs and wants (Aycock, Garnham, \& Kaleta 2002; Richardson \&long, 2003, as cited in Tao, et al., 2011). With respect to interaction, the results indicated significant impact of using Blackboard $\AA$ on students' satisfaction in developing students' skills and language area (Bueno-Alastuey \& Lopez-Perez, 2014). This specifically, was noticed on improving oral and written interaction, and developing listening skills, which means as Aliweh (2011) found that students' satisfaction might considerably improve if they can relate to the supplementary content.

Taken both into consideration, these findings suggest that using Blackboard ${ }^{\circledR}$ to provide supplementary materials in BL mode enhanced students' satisfaction. Specifically, the satisfaction was noticed about learning resources, use of English language, and use of Blackboard ${ }^{\circledR}$ as LMS. However, the study showed significant results about students' unwillingness to use it in future for both supplementary purpose or for conducting exams. This may suggest the importance for empowering students' attitude towards using technology in learning and independent learning to help them improve their study skills.

\subsection{Implications}

Based on the review of BL literature, there is a high demand for further research in this area. In particular, the shortage of BL research in EFL emphasizes the need for more research. Thus, further research investigating the perceptions of EFL students and teachers towards BL are recommended. It is suggested to examine the motivational behavior of both the teachers and the students as well as to investigate the factors that could lead to high motivation and successful BL environment. Thus, it is recommended to explore which factors will affect the environment of $\mathrm{BL}$ in EFL, in order to find the best ways to adopt BL in English language centers. Furthermore, evaluating the Blackboard $\AA$ as LMS in terms of it efficiency in comparison to other modern LMS, in order to overcome the difficulties of using LMS. 


\subsection{Challenges and Limitations}

Due to the new emergence of BL in Saudi Arabia, it was challenging to find extensive literature that addresses BL in a Saudi EFL context. The scarce number of studies that considered the use of Blackboard ${ }^{\circledR}$ in EFL contexts, left the researchers to consult similar studies that focused on BL. However, it was somehow a challenge to use Blackboard ${ }^{\circledR}$ at the ELI due to its new emergence at KAU. Implementing Blackboard ${ }^{\circledR}$ for onsite students took unexpected delays in time, which affected the progress of the study. Besides, providing the teachers with access to the course in Blackboard ${ }^{\circledR}$ was a major challenge.

\section{Acknowledgments}

We would like to extend our sincere gratitude to Dr. Norah Al Maliki who encouraged us to complete this work in the Deanship of e-learning \& Distance learning at KAU. Also, we would like to specially thank Dr. Susan Duncan, Ms. Laura Davis, Ms. Dominika Legień and Mr. Hussam Rajab for their support.

\section{References}

Al-Buasaidi, K. A., \& Al-Shihi, H. (2012). Key features to instructors' management system in BL. Journal of Computing in Higher Education, 24(1), 18-39. https://doi.org/10.1007/s12528-011-9051-x

Aliweh, A. M. (2011). Exploring Egyptian EFL students learning styles and satisfaction with web-based materials. CALICO Journal, 29(1), 81-99. https://doi.org/10.11139/cj.29.1.81-99

Assalahi, H. (2015). The philosophical foundation of educational research: A beginner's guide. Science \& Education Publishing, 3(3), 312-317. https://doi.org/10.12691/education-3-3-10

Blended Learning Theory and Design Principles. Retrieved November 12, 2014, from https://tle.wisc.edu/blend/design/principles

Bray, E., Aoki, K., \& Dlugosh, L. (2008). Predictors of learning satisfaction in Japanese online distance learners. International Review of Research in Open and Distance Learning, 9(3), 1-24. https://doi.org/10.19173/irrodl.v9i3.525

Brew, L. S. (2008). The role of student feedback in evaluating and revising a blended learning course. Internet and Higher Education, 11, 98-105. https://doi.org/10.1016/j.iheduc.2008.06.002

Brooks, J. G., \& Brooks, M. G. (1993). In Search of Understanding: The Case For Constructivist Classrooms. Alexandria, VA: Association for supervision and Curriculum Development.

Bruner, J. S. (1960). The process of education. Cambridge, MA: Harvard University.

Bueno-Alastuey, M. C., \& López Pérez, M. V. (2014). Evaluation of a blended learning language course: students' perceptions of appropriateness for the development of skills and language areas. Computer Assisted Language Learning, 27(6), 509-527. https://doi.org/10.1080/09588221.2013.770037

Chang, K.-Y. (2011). Factors affecting student satisfaction in different learning deliveries. Unpublished doctoral dissertation, Illinois State University. Illinois, USA.

Chen, N.-S., Wei, C. W., Chen, Y. R., \& Wan, T. C. (2008). Bridging the gap between face-to-face and cyber interaction in holistic blended learning environments. In H. H. Adelsberger, J. M. Pawlowski, \& D. Sampson (Eds.). Handbook on information technologies for education and training. Berlin: Springer. https://doi.org/10.1007/978-3-540-74155-8_13

Cohen, D, Crabtree B. Qualitative research guidelines project. Retrieved May 7, 2015, from http://www.qualres.org/HomePosi-3515.html

Dziuban, C., Hartman, J., Juge, F., Moskal, P., \& Sorg, S. (2006). Blended learning enters the mainstream. In C. J. Bonk, \& C. R. Graham (Eds.), The handbook of blended learning: Global perspectives, local designs (pp. 195-206). San Francisco: Pfeiffer.

Fosnot, C. T. (1996). Constructivism: Theory, Perspectives, and Practice. New York: Teachers College Press.

Garrison, R., \& Kanuka, H. (2004). Blended learning: Uncovering its transformative potential in higher education. Internet and Higher Education, 7, 95-105. https://doi.org/10.1016/j.iheduc.2004.02.001

Graham, C. R., Allen, S., \& Ure, D. (2003). Blended learning environment: A review of the research literature. Unpublished manuscript, Provo, UT. 
Graham, C. R., (2004). Definition, current trends, and future directions. In C. J. Bonk, \& C. R. Graham (Eds.). (2006). Handbook of blended learning: Global Perspectives, local designs. Francisco, CA: Pfeiffer Publishing.

Graham, C. (2006). Blended learning systems. Definitions, current trends and future directions. In C. Bonk, \& C. Graham (Eds.) (2012), The handbook of blended learning: Global perspectives, local designs. San Francisco: John Wiley and Sons.

Heinze, A. (2008). Blended learning: An interpretive action research study. Unpublished Doctoral dissertation, Informatics Research Institute, Salford Business School University of Salford, UK. Retrieved February 10, 2015, from http://usir.salford.ac.uk/1653/1/Heinze_2008_blended_e-learning.pdf

Kashghari, B., \& Asseel, D. (2014). Collaboration and interactivity in EFL learning via Blackboard ${ }^{\circledR}$ Collaboration: A pilot study. International Conference ICT for Language Learning.

Kerres, M., \& C. de Witt (2003). A didactical framework for the design of blended learning arrangements. Journal of Educational Media, 28, 101-114. https://doi.org/10.1080/1358165032000165653

Kobayashi, K., \& Little, A. (2011). Perceptions on the usefulness of a blended learning EFL program. JALTCALL Journal, 7(1), 103-117.

Laurillard, D. (2002). Rethinking university teaching: A conversational framework for the effective use of learning technologies (2nd $\quad$ ed.). London, UK: Routledge Falmer. https://doi.org/10.4324/9780203304846

Liang, M.Y, \& and Curtis J. \& Bonk, C. J. (2009). Interaction in blended EFL learning: principles and practice. International Journal of Instructional Technology and Distance Learning, 6(1).

Lyons, T., \& Evans, M. M. (2013). Blended Learning to Increase Student Satisfaction: An Exploratory Study. Internet Reference Services Quarterly, 18(1), 43-53. https://doi.org/10.1080/10875301.2013.800626

Marsh, D. (2012). Blended learning: Creating learning opportunities for language learners. New York: Cambridge University Press.

McGregor, S. L. T., \& Murnane, J. A. (2010). Paradigm, methodology and method: Intellectual integrity in consumer scholarship. International Journal of Consumer Studies, 34(4), 419-427. https://doi.org/10.1111/j.1470-6431.2010.00883.x

Mitchell, A., \& Honore, S. (2007). Criteria for successful blended learning. Industrial and Commercial Training, 39(3), 143-149. https://doi.org/10.1108/00197850710742243

Neumeier, P. (2005). A closer look at blended learning: Parameters for designing a blended learning environment for language teaching and learning. Recall, 17(2), 163-178. https://doi.org/10.1017/S0958344005000224

Nguyen, B. T. (2013). Face-to-face, blended, and online instruction: Comparison of student performance and retention in higher education. Unpublished doctoral dissertation. Retrieved February 22, 2015, from proQuest digital Dissertations. (AAT 3499473)

Osgerby, J. (2013). Students' perceptions of the introduction of a blended learning environment: An exploratory case study. Accounting Education, 22(1), 85-99. https://doi.org/10.1080/09639284.2012.729341

Pena, M. I. C., \& Yeung, A. S. (2010). Satisfaction with online learning: Does students' computer competence matter? The International Journal of Technology, Knowledge and Society, 6(5), 97-108. https://doi.org/10.18848/1832-3669/CGP/v06i05/56148

Perry Jr, F. L. (2008). Research in applied linguistics: Becoming a discerning consumer. Londoan: Lawrence Erlbaum Associates.

Richardson, J. T. E., \& Long, G. L. (2003). Academic engagement and perceptions of quality in distance education. Open Learning, 18(3), 223-244. https://doi.org/10.1080/0268051032000131008

Ryan, A. B. (n.d.). Post-positivist approaches to research. Retrieved May 7, 2015, form http://eprints.maynoothuniversity.ie/874/1/post-positivistapproachestoresearch. pdf

Schumm, W. R., Webb, F. J., Turek, D. E., Jones, K. D., \& Ballard, G. E. (2006). Acomparison of methods for teaching critical thinking skills for U.S. army officers. American Journal of Distance Education, 20(1), 39-50. https://doi.org/10.1207/s15389286ajde2001_4

Singh, H. (2003). Building effective blended learning programs. Educational Technology, 43(6), 51-54. 
Sousa, V., Driessnack, M., \& Mendes, I. (2007). An overview of research designs relevant to nursing: Part 1 Quantitative research designs. Revista Latino- Americana de Enfermagem, 15(3), 502-507. https://doi.org/10.1590/S0104-11692007000300022

Tao, J., Fore, C., \& Forbes, W. (2011). Seven best face-to-face teaching practices in a blended learning environment. Journal of Applied Learning Technology, 1(3), 20-29.

University of Wisconsin-Madison. (2014). Blended learning theory and design principles. Retrieved: November 12, 2014, from https://tle.wisc.edu/blend/design/principles, Siemens

Whitelock, D., \& Jelfs, A. (2003) Editorial: Journal of Educational Media Special Issue on Blended Learning. Journal of Educational Media, 28(2-3), 99-100. https://doi.org/10.1080/1358165032000177407

Wilson, N., \& McLean, S. (1994). Questionnaire design: A practical introduction. Newtown Abbey: University of Ulster Press.

Yilmaz-Soylu, B. A. (2008). Development of a scale on learners' views on blended learning and its implementation process. Internet and Higher Education, 26-32.

Yusuf, A. (2002). Inter-relationship among academic performance, academic achievement and learning outcomes. Journal of Curriculum and Instruction, 1(2), 87-96.

\section{Copyrights}

Copyright for this article is retained by the author(s), with first publication rights granted to the journal.

This is an open-access article distributed under the terms and conditions of the Creative Commons Attribution license (http://creativecommons.org/licenses/by/4.0/). 